\title{
Metformin inhibits growth and sensitizes osteosarcoma cell lines to cisplatin through cell cycle modulation
}

\author{
IRENE QUATTRINI $^{1}$, AMALIA CONTI $^{1}$, LAURA PAZZAGLIA $^{1}$, CHIARA NOVELLO $^{1}$, \\ STEFANO FERRARI $^{2}$, PIERO PICCI ${ }^{1}$ and MARIA SERENA BENASSI ${ }^{1}$ \\ ${ }^{1}$ Laboratory of Experimental Oncology and ${ }^{2}$ Chemotherapy Ward, Rizzoli Orthopaedic Institute, I-40136 Bologna, Italy
}

Received June 12, 2013; Accepted July 22, 2013

DOI: 10.3892/or.2013.2862

\begin{abstract}
Osteosarcoma (OS) is the most common cancer that affects the bone and appears to be resistant to several chemotherapeutic drugs. The aim of the present study was to verify whether the combination of metformin and cisplatin has an effect on OS cell lines. OS cell lines U2OS, 143B and MG63 were treated with metformin, cisplatin or a combination of both drugs. Viability, apoptosis and cell cycle were evaluated to characterize the effects of the treatments. Western blot analyses were used to evaluate protein expression. All OS cell lines were found to be sensitive to metformin with different values of $\mathrm{IC}_{50}$, showing a slowdown of cell cycle associated or not with apoptosis. In particular, metformin was able to sensitize cells to cisplatin, to which all OS cell lines were resistant, demonstrating a synergistic effect in the combined treatment of the two drugs. The data obtained may have clinical relevance for novel therapeutic strategies for the treatment of OS; metformin inhibits tumor cell growth and amplifies the effect of cisplatin.
\end{abstract}

\section{Introduction}

Osteosarcoma (OS), the most common tumor of the bone, is a rare malignant neoplasm affecting mostly children and adolescents. Although long-term survival in high-grade OS has markedly improved in the last decades, owing to neoadjuvant chemotherapy (1), data emerging from clinical studies show that $35-45 \%$ of OS patients have a natural or acquired drug-resistance (2).

The possibility of identifying tumor molecular background and signaling pathway key end-points may provide new targets for planning tailored therapies combined with conventional therapeutic modalities (3).

Correspondence to: Dr Maria Serena Benassi, Laboratory of Experimental Oncology, Rizzoli Orthopaedic Institute, Via di Barbiano 1/10, I-40136 Bologna, Italy

E-mail: mariaserena.benassi@ior.it

Key words: metformin, cisplatin, osteosarcoma, cell cycle, protein expression
Metformin (1,1-dimethylbiguanide hydrochloride) belongs to the biguanide class of oral hypoglycemic agents and is widely used as an antidiabetic drug $(4,5)$ by regulating glucose homeostasis and reducing insulin resistance.

Recent evidence indicates that metformin may reduce the risk of cancer and improve prognosis and that in patients with type 2 diabetes it reduces the risk of cancer (6-8).

In vitro and in vivo data (2,9-11) emphasized the role of 5'-monophosphate-activated protein kinase (AMPK) in action mechanism of metformin and demonstrated that the reduction of tumor cell proliferation and survival is mediated by inactivation of mTOR in both insulin-dependent and -independent pathways (12).

AMPK is a heterotrimeric serine/threonine kinase composed of a catalytic $\alpha$ subunit, and two regulatory subunits, $\beta$ and $\gamma(13,14)$. Activation of AMPK requires an allosteric change induced by AMP, as well as phosphorylation at Thr172, that inhibits the downstream target mTOR implicated in protein synthesis and proliferation (15) and promotes vascular endothelial growth factor expression and angiogenesis (16-20).

In vitro and in vivo studies demonstrated that metformin inhibits tumor cell growth and survival in numerous tumors (8,21-23), emphasizing its role as an antineoplastic agent through a variety of responses including inhibition of growth factor signaling pathway, and/or cell arrest in G1 phase $(8,24,25)$.

The present study investigated the antitumor effects of metformin on OS cell lines alone and in combination with cisplatin (CDDP), a DNA-damaging chemotherapeutic drug frequently used in OS patients.

Findings of the present study indicated that metformin may sensitize OS cells to CDDP through inactivation of critical intracellular end-points and lengthening of cell cycle phases.

\section{Materials and methods}

Reagents. Anti-cyclin D1 (HD11) and anti-p-p53 (hSer20) were obtained from Santa Cruz Biotechnology, Inc. (Santa Cruz, CA, USA). Anti-phospho AMPK $\alpha$ (Thr172), anti-AMPK $\alpha$, anti-phospho-p70S6K (S6K1) (Thr389), anti-IGF-1R $\beta$, anti-phospho Chk1 (Ser345) were purchased from Cell Signaling Technology (Beverly, MA, USA). Anticyclin A and anti-cyclin E were obtained from Calbiochem, Merck KGaA, (Darmstadt, Germany). Anti-actin was from 
Sigma Chemical Co., (St. Louis, MO, USA). Horseradish peroxidase-conjugated anti-rabbit IgG, anti-mouse IgG were purchased from GE Healthcare. Enhanced chemiluminescent substrate LiteAblot Plus was obtained from EuroClone S.p.A (Pero, Milan, Italy).

Metformin was obtained from Sigma-Aldrich Biotechnology (St. Louis, MO, USA), and diluted in PBS $1 \mathrm{X}$ to make a $1 \mathrm{M}$ stock solution that was stored at $-20^{\circ} \mathrm{C}$. It was used across a range of concentrations at $0,5,10,20$ and $40 \mathrm{mM}$ diluted in media.

Cisplatin was purchased by Teva Pharmaceuticals B.V. (Utrecht, The Netherlands) and was stored at $4^{\circ} \mathrm{C}$; it was used across a range of concentrations at $0.01,0.1,1.0,10$ and $100 \mathrm{ng} / \mathrm{ml}$ diluted in media.

Cell lines and culture conditions. Human OS cell lines U2OS (pRB+/+, p53+/+), 143B (pRB+/+, p53+/+) and MG63 (pRB+/+, p53-/-) were obtained from the American Type Culture Collection (ATCC, Rockville, MD, USA) and cultured in Dulbecco's modified Eagle's medium (DMEM) supplemented with $10 \%$ fetal bovine serum (FBS), L-glutamine $(2 \mathrm{mM})$, $100 \mathrm{U} / \mathrm{ml}$ penicillin and $100 \mu \mathrm{g} / \mathrm{ml}$ streptomycin (Invitrogen) at $37^{\circ} \mathrm{C}$ in a $5 \% \mathrm{CO}_{2}$ humidified incubator. Cells were routinely passed when they reached $\sim 80 \%$ confluence.

Cell growth and sensitivity study. The number of adherent, viable cells was assessed microscopically using an improved Neubauer haemocytometer and proliferation was assessed as the percentage of cells that excluded $0.2 \%$ trypan blue. Cells were seeded at 100,000/well in 6-well plates and incubated in medium containing $10 \%$ FBS. Twenty-four hours after seeding, cells were treated either with or without increasing doses of metformin $(0,5,10,20$ and $40 \mathrm{mM})$ for 24,48 and 72 h. After 24, 48 and 72 h, cells were washed once with Dulbecco's phosphate-buffered saline (PBS) 1X, harvested by trypsinization and cell number was determined using trypan blue.

$\mathrm{IC}_{50}$ and $\mathrm{IC}_{30}$ values, defined as the concentration of drugs inhibiting cell growth by 50 and $30 \%$, respectively, were calculated for experiments with $72 \mathrm{~h}$ of treatment.

Cells were also treated with increasing doses of CDDP $(0.01,0.1,1.0,10$ and $100 \mathrm{ng} / \mathrm{ml})$ and cytotoxicity was evaluated as cell viability up to $72 \mathrm{~h}$.

For combined treatment, cells were treated at the same time in combination with metformin $\mathrm{IC}_{30}$ and CDDP at different concentrations for $72 \mathrm{~h}$; cells were also treated in sequential manner with metformin $\mathrm{IC}_{30}$ for $72 \mathrm{~h}$, followed by $24 \mathrm{~h}$ of CDDP treatment at different concentrations.

Flow cytometry for apoptosis. OS cells were seeded at $100,000 /$ well in 6-well plates, allowed to attach overnight, and incubated with or without an $\mathrm{IC}_{50}$ dose of metformin for 48 and $72 \mathrm{~h}$. According to the protocol kit (MEBCYTO Apoptosis kit; MBL International, Woburn, MA, USA), the adherent cells were trypsinized, detached, and combined with floating cells from the original growth medium, centrifuged and washed twice with PBS 1X. Cells were re-suspended in $500 \mu 1$ of staining solution containing FITC-conjugated Annexin V antibody and propidium iodide (PI) for $30 \mathrm{~min}$ and analyzed by flow cytometry.
The number of viable (Annexin-/PI-), apoptotic (Annexin+/ PI-) and necrotic (Annexin+/PI+) cells were determined with the CellQuest Software (BD Biosciences, San Jose, CA, USA), using a peak fluorescence gate to exclude cell aggregates during cell cycle analysis in a FACSCalibur flow cytometer (Becton-Dickinson, San Jose, CA, USA).

Cell cycle analysis by FACS. OS cells were plated in 6-well plates $(100,000$ cells/well), allowed to attach overnight, and incubated with $\mathrm{IC}_{50}$ doses of metformin. After 48 and $72 \mathrm{~h}$ they were harvested by trypsinization, fixed with $70 \%$ ethanol and washed with appropriate buffer (PAT) several times. After $\alpha$-bromodeoxyuridine incorporation and $\alpha$-mouse FITC incubation as secondary antibody, cells were stained for total DNA content with a solution containing PI (1:5 in PAT). Cell cycle distribution was then analyzed with a FACScan flow cytometer (Becton-Dickinson).

Protein extraction and western blot analysis. Expression levels of proteins were determined by western blot analysis. After $48 \mathrm{~h}$ of $\mathrm{IC}_{50}$ metformin incubation, cells were washed three times with PBS and lysed in 100-400 $\mu 1$ lysis buffer [20 mM Tris- $\mathrm{HCl}$ (pH 7.5)], $150 \mathrm{mM} \mathrm{NaCl,} 2.5 \mathrm{mM}$ sodium pyrophosphate, $1 \mathrm{mM} \beta$-glycerol phosphate, $1 \mathrm{mM} \mathrm{Na} \mathrm{VO}_{4}$, $1 \mathrm{mM}$ EGTA, 1\% Triton and complete protease inhibitor mixture inhibitors from Roche Diagnostics (Laval, QC, Canada). Cellular debris was removed by centrifugation at $14,000 \mathrm{x}$ g for $20 \mathrm{~min}$ at $4^{\circ} \mathrm{C}$. Following assay for total protein (Bio-Rad Laboratories, Mississauga, ON, Canada), clarified protein lysates $(50 \mu \mathrm{g})$ were boiled for $5 \mathrm{~min}$ and analyzed by 8.0-15\% SDS-polyacrylamide gel, followed by blotting at $40 \mathrm{~V}$ for $1 \mathrm{~h}$ and $100 \mathrm{~V}$ for $2 \mathrm{~h}$. Blots were probed with anti-p-p53 (Ser20) (1:200), anti-IGF-IR $\beta$ (1:200), anti-phospho-AMPK $\alpha$ (Thr172) (1:1,000), anti-AMPK $\alpha(1: 1,000)$, anti-phosphop70S6K (S6K1) (Thr389) (1:1,000), anti-phospho Chk1 (Ser345) (1:1,000), anti-cyclin A (1:300), anti-cyclin E (1:200), and anti-cyclin D1 (1:200). Horseradish peroxidase-conjugated anti-rabbit IgG or anti-mouse IgG were used as secondary antibodies. The signal was visualized by enhanced chemiluminescent substrate LiteAblot Plus (EuroClone S.p.A.) and quantified using GS-800 imaging densitometer (Bio-Rad Laboratories, Hercules, CA, USA). A rabbit anti-actin antibody was used as control.

Statistical analysis. All experiments were performed three times and results are expressed as means \pm SD. Significance was analyzed by the Student's t-test and a probability value of $\mathrm{P} \leq 0.05$ was considered to indicate a statistically significant difference.

\section{Results}

Susceptibility of OS cell lines to metformin. When OS cell lines were exposed to increasing doses of metformin (0-40 mM), a progressive loss of proliferation up to $72 \mathrm{~h}$ was observed when cell growth decreased by $75 \%$ for U2OS, $89 \%$ for MG63 and $82 \%$ for 143B (Fig. 1).

Cell sensitivity evaluation indicated that U2OS, MG63 and 143B were sensitive to metformin with $\mathrm{IC}_{50}$ mean values at $72 \mathrm{~h}$ of $9.13 \pm 0.3,8.72 \pm 0.4$ and $7.29 \pm 0.7$, respectively, and $\mathrm{IC}_{30}$ mean values of $4.11 \pm 0.7,6.2 \pm 1.1$ and $3.2 \pm 0.4$, respectively. 

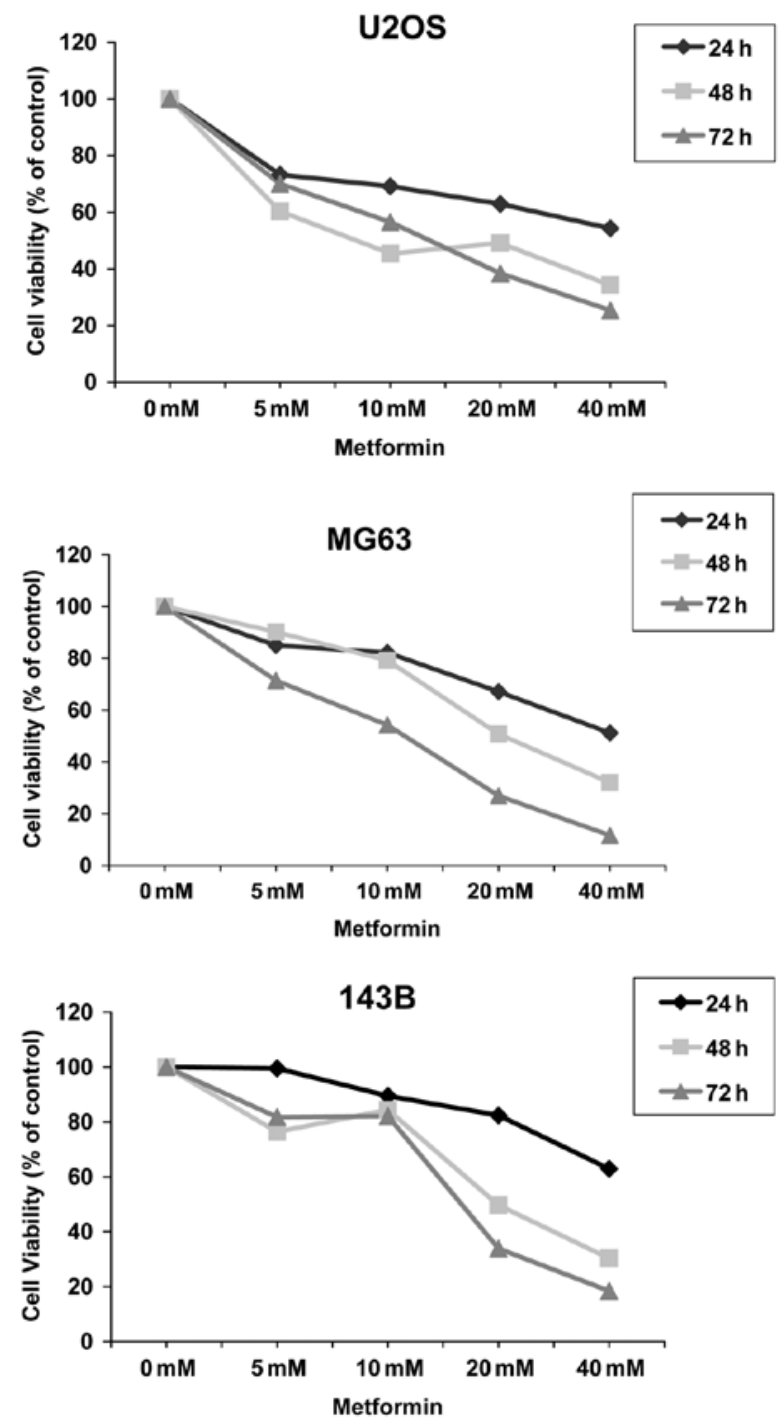

Figure 1. Sensitivity of OS cell lines to metformin. Cells were exposed to increasing doses of metformin $(0,5,10,20$ and $40 \mathrm{mM})$ for 24,48 and $72 \mathrm{~h}$. Significant loss of proliferation occurred at $72 \mathrm{~h}$ (75\% U2OS, 89\% MG63, $82 \% 143 \mathrm{~B}$ ) by counting with trypan blue. Each point indicates the average of three independent experiments.

Effect of metformin on cell cycle and apoptosis. Following exposure of $\mathrm{U} 2 \mathrm{OS}$ to $\mathrm{IC}_{50}$ dose of metformin, cell cycle analysis revealed a transient arrest in $\mathrm{G} 2$ phase at $48 \mathrm{~h}$, while a longer exposure $(72 \mathrm{~h}$ ) caused accumulation of cells in $\mathrm{S}$ phase (Fig. 2) with a significant time-dependent induction of apoptosis (from $4.6 \%$ in non-stimulated cells to 17.2 and $21.7 \%$, respectively, in stimulated cells) (Fig. 3).

Conversely, $143 \mathrm{~B}$ responded to the $\mathrm{IC}_{50}$ doses of metformin with relevant arrest of cells in G1 at $48 \mathrm{~h}$ associated with a decrease of number of cells in $\mathrm{S}$ and $\mathrm{G} 2$ phase. The following $72 \mathrm{~h}$ treatment resulted in lengthening of $\mathrm{S}$ phase, concomitant with a significant decrease of $\mathrm{G} 2$ phase (Fig. 2) and a moderate induction of apoptosis when compared to non-treated cells (8.10\% non-treated cells, $8.86 \%$ at $48 \mathrm{~h}$ and $11.20 \%$ at $72 \mathrm{~h}$ ) (Fig. 3).

In MG63, metformin treatment was effective only at the $72 \mathrm{~h}$ with accumulation of cells in G1 and G2 phases concomitant with strong decrease in S phase (Fig. 2). No cases showed
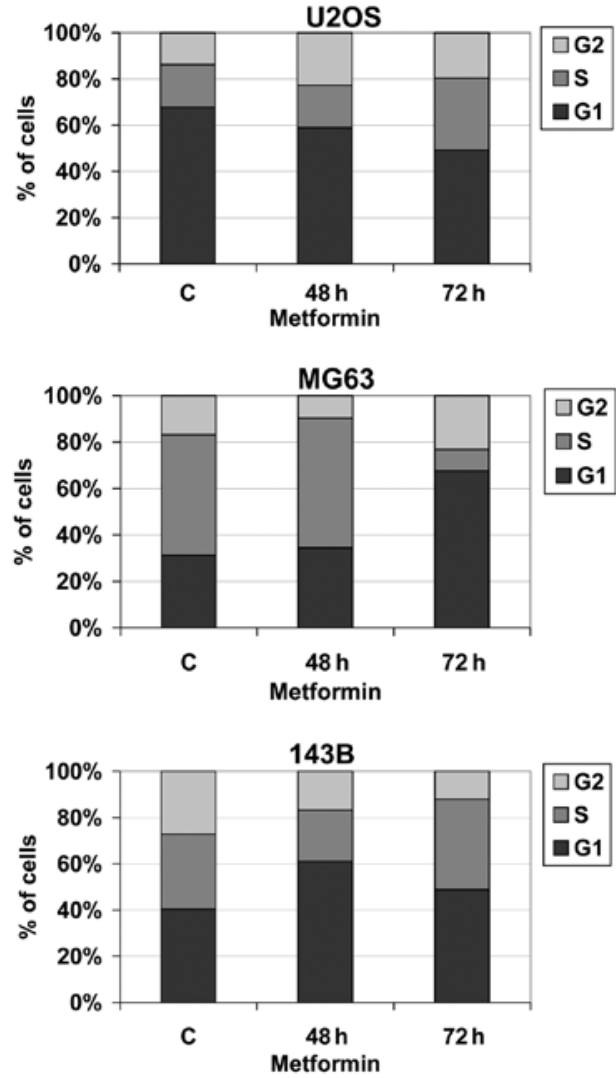

Figure 2. U2OS, MG63 and 143B cell cycle analysis by flow cytometry, after exposure to $\mathrm{IC}_{50}$ doses of metformin for 48 and $72 \mathrm{~h}$. Histograms show distribution of cells in G1, S or G2 phases of cell cycle.
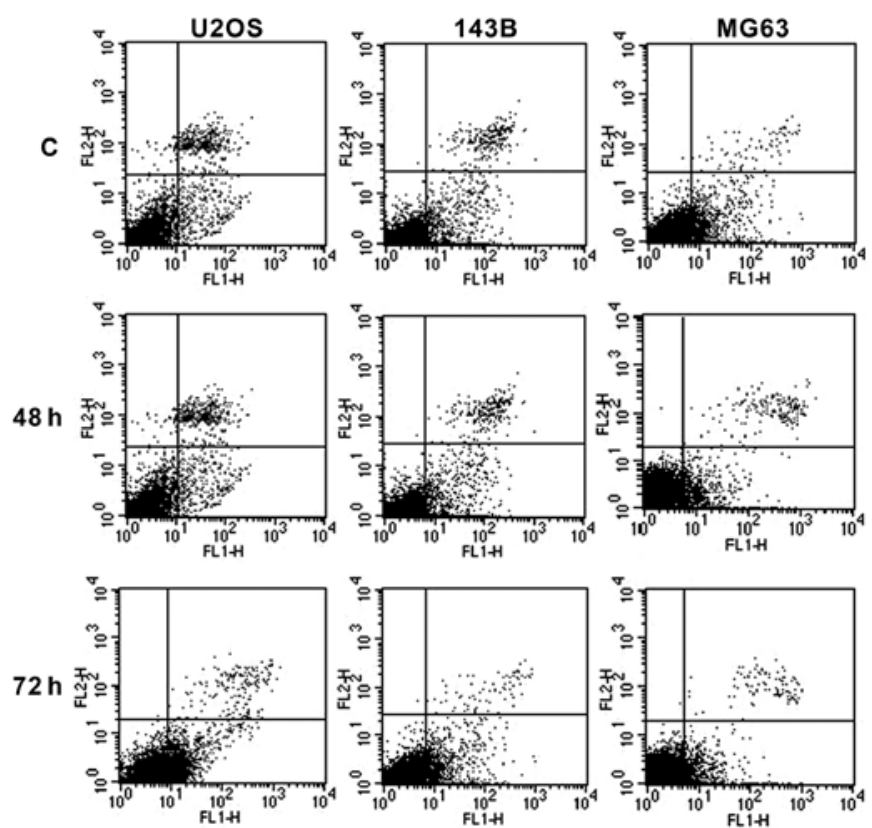

Figure 3. U2OS, 143B and MG63 apoptosis by flow cytometry. OS cells were exposed to $\mathrm{IC}_{50}$ dose of metformin for 48 and $72 \mathrm{~h}$. U2OS showed a timedependent induction for apoptosis. MG63 and 143B showed no or minimal apoptotic induction after treatment.

apoptotic induction by Annexin V-FITC assay (7.6\% in nontreated cells, $6.79 \%$ at $48 \mathrm{~h}, 8 \%$ at $72 \mathrm{~h}$ ) (Fig. 3), suggesting a predominant cytostatic effect of metformin exposure. 


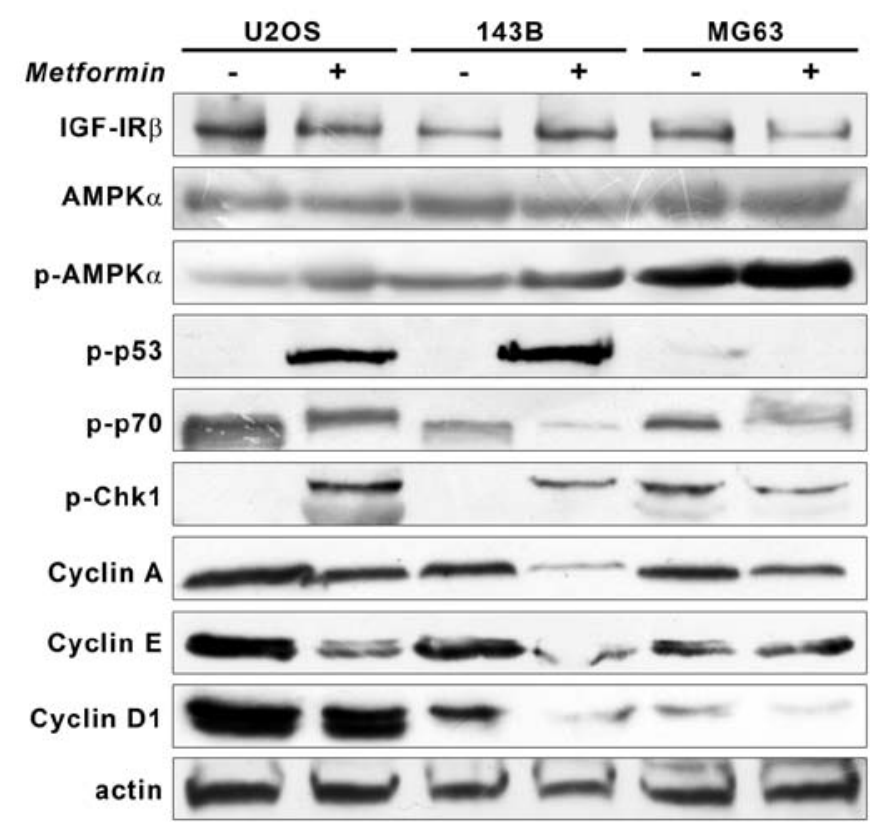

Figure 4. Western blot analysis. Effects of metformin on intracellular signaling and cell cycle proteins in OS cell lines. Cells were treated with or without $\mathrm{IC}_{50}$ metformin for $48 \mathrm{~h}$. All OS cell lines were positive to IGF-IR $\beta$ and AMPK $\alpha$; all OS lines showed an increase of p-AMPK $\alpha$ after treatment as well as for p53 Ser20 except for MG63 (p53-/-). Phospho-p70 was reduced in all cell lines while Chk1 was increased. Cyclin expression was associated with cell cycle phase arrest induced by metformin treatment. Rabbit antiactin antibody was used as control.

Protein analysis. All OS cell lines were positive to IGF-IR $\beta$ and total AMPK $\alpha$ without showing changes in expression levels after metformin exposure. However, at $48 \mathrm{~h}$ of $\mathrm{IC}_{50}$ treatment, phosphorylation level of p-AMPK $\alpha$ Thr172 increased in all cell lines and accumulation of p53 (Ser20) was seen in wild-type-p53 U2OS and 143B.

p70S6K phosphorylated at Thr389, substrate of mTOR activity, markedly decreased after treatment (Fig. 4).

When proteins involved in cell cycle control were analyzed, both wild-type U2OS and 143B cells showed increased expression of Chk1 (Ser345) associated with downregulation of active cyclin A and cyclin E. No significant changes in the volume of electrophoretic bands were seen for MG63. In parallel, we observed a loss of cyclin D1 expression in 143B and MG63 and to a lesser extent in U2OS (Fig. 4).

Susceptibility of OS cell lines to CDDP. All OS cell lines were exposed to increasing doses of CDDP up to $100 \mathrm{ng} / \mathrm{ml}$ for $72 \mathrm{~h}$; MG63 and 143B did not show cell growth inhibition, while U2OS had a slight reduction of $30 \%$ with the maximum dose of CDDP (Fig. 5).

Metformin sensitizes OS cells to CDDP. First U2OS, 143B and MG63 were exposed to increasing concentrations of cisplatin (0.01-100 ng/ml) combined with sub-toxic doses of metformin $\left(\mathrm{IC}_{30}\right)$ for $72 \mathrm{~h}$.

Data demonstrate that U2OS and 143B responded to simultaneous treatment with reduction of cell proliferation of $33 \%$ $(\mathrm{P}<0.01)$ and $60 \%(\mathrm{P}<0.001)$, respectively, when compared with CDDP alone showing a synergistic effect up to $1.0 \mathrm{ng} / \mathrm{ml}$
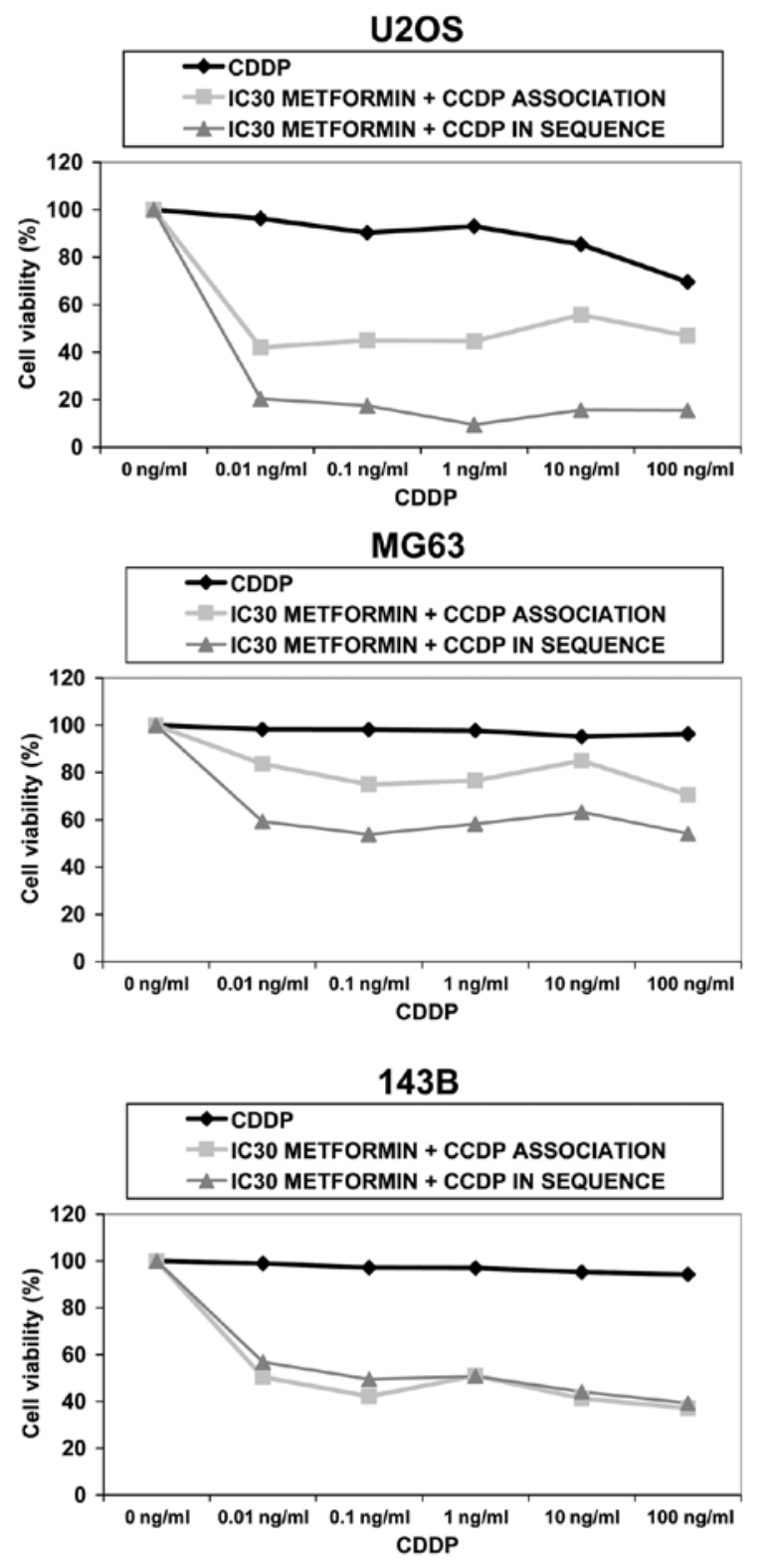

Figure 5. Effect of combined treatment in OS cell lines compared to CDDP alone. Cells were exposed to increasing doses of CDDP alone $(0.01-100 \mathrm{ng} / \mathrm{ml})$ and combined with sub-toxic doses $\left(\mathrm{IC}_{30}\right)$ of metformin at the same time and at two different times.

of CDDP for U2OS and $100 \mathrm{ng} / \mathrm{ml}$ for 143B. MG63 responded to a lesser extent by reduction of cell proliferation of $27 \%$ $(\mathrm{P}<0.05$ at maximum dose of CDDP). An antagonistic effect was observed between the two drugs at any dose.

Subsequently, we evaluated whether pre-treatment with metformin better sensitizes OS cells to CDDP treatment by administering the drugs in sequence. OS cells were exposed to $\mathrm{IC}_{30}$ metformin for $72 \mathrm{~h}$, followed by increasing doses of CDDP for $24 \mathrm{~h}$.

In U2OS and MG63, cell proliferation dropped by $78 \%$ $(\mathrm{P}<0.001)$ and $44 \%(\mathrm{P}<0.01)$, respectively, with respect to CDDP alone, while 143B responded with a percentage of decrease equal to that of simultaneous treatment $(60 \%)$ $(\mathrm{P}<0.01)$ (Fig. 5).

When CDDP was administered after metformin, a synergistic interaction was seen in all cell lines. 


\section{Discussion}

The first choice in OS treatment consists of combined chemotherapeutic treatments often associated with serious problems, such as frequent acquisition of drug-resistant phenotypes and toxic side-effects that impair the quality and expectancy of life in sarcoma patients.

Identification of critical end-points implicated in the control of tumor cell survival (26) may provide the rationale for new combined regimens able to overcome conventional treatment failure.

Several experimental approaches have demonstrated the therapeutic potential of mTOR inhibitors (27) and the strengthening of cell response to anticancer agents through checkpoint activation and arrest of cell cycle $(28,29)$.

Evidence shows that metformin may inhibit tumor cell growth (30) and enhance the effect of chemotherapy through different anticancer mechanisms including insulin-dependent and/or -independent activity $(12,31)$.

Our data show that OS cell lines differing in proliferation, transmigration and genetic background (32) respond to metformin by decreasing cell proliferation through cell cycle lengthening associated or not with apoptosis induction.

This effect appears to be correlated with increased expression of AMPK $\alpha$ phosphorylated at Tyr172 and inhibition of mTOR downstream signaling pathway measured by dephosphorylation of p70S6K, resulting in an inhibition of protein synthesis and cell growth (33).

Some reports support the hypothesis that inhibition of cell proliferation by AMPK $\alpha$ activation is determined other than by mTOR signaling inhibition, by arresting cell cycle through activation of phospho-p53 and downregulation of cyclindependent kinase (CDK) activity $(34,35)$.

It is well known that cell cycle is regulated by phosphorylation and dephosphorylation events controlled by CDK/cyclin complexes and CDK inhibitors that arrest cell growth at G1/S and/or G2/M checkpoints $(28,36)$.

Our data showed that in wt-p53 U2OS and 143B cell lines, metformin treatment induced accumulation of p53 (Ser20) associated with apoptosis induction and prevalent lengthening of $\mathrm{S}$ phase after long-term exposure $(72 \mathrm{~h})$. This delay in cell cycle progression resulted from activation of phospho-Chk1 at Ser345 that activates S and G2 checkpoints through downregulation of cyclin A and cyclin E. Evidence that Chk1 contributes to cell cycle checkpoints in human cells comes from studies showing that Chk1 is an important regulator of $S$ phase arrest and its disruption abrogates $S$ and G2 checkpoints $(37,38)$. These events may contribute to sensitize our wt-p53 OS cell lines to CDDP showing a synergistic effect with metformin both in combined and sequence treatments. Null-p53 MG63 where no activation of phospho-Chk1 was seen, responded to long-term exposure of metformin with prevalent accumulation of cells in G1 associated with downregulation of cyclin D1 without apoptosis induction, suggesting cytostatic rather than cytotoxic effect. Ben Sahra et al (8) demonstrated that in prostate cancer, the block of cell cycle in G1 by metformin is not mediated by the AMPK pathway. By contrast, in breast cancer, inhibitors of AMPK induced downregulation of D1 and G1 arrest even in mut-p53 cells (35).
Moreover, CDDP in sequence with metformin was more effective in decreasing MG63 cell proliferation than in simultaneous treatment, where the two agents presented antagonistic effects.

These results show that treatment with metformin induces significant growth inhibition of OS cell lines through arrest of cell cycle and decrease of S6K activity mediated by AMPK $\alpha$ phosphorylation. In addition, metformin may sensitize OS cells otherwise resistant to CDDP in a p53-independent manner through synergistic drug-drug interaction.

Our data may have clinical relevance for novel therapeutic strategies for the treatment of OS.

\section{Acknowledgements}

The authors thank Cristina Ghinelli and Alba Balladelli for their help in editing the manuscript. Chiara Novello was supported by the Fondazione Italiana per la Ricerca sul Cancro (FIRC); triennial fellowship 'Mario e Valeria Rindi' 20132015 (research project no. 13748). This study was supported by the Italian Ministry of Public Health and 5\% donation (Italy).

\section{References}

1. Picci P, Mercuri M, Ferrari S, Alberghini M, Briccoli A, Ferrari C, Pignotti E and Bacci G: Survival in high-grade osteosarcoma: improvement over 21 years at a single institution. Ann Oncol 21: 1366-1373, 2010.

2. Hattinger CM, Pasello M, Ferrari S, Picci P and Serra M: Emerging drugs for high-grade osteosarcoma. Expert Opin Emerg Drugs 15: 615-634, 2010.

3. Liotta LA and Petricoin E: Cancer biomarkers: closer to delivering on their promise. Cancer Cell 20: 279-280, 2011.

4. Stumvoll M, Nurjhan N, Perriello G, Dailey G and Gerich JE: Metabolic effects of metformin in non-insulin-dependent diabetes mellitus. N Engl J Med 333: 550-554, 1995.

5. Zhou G, Myers R, Li Y, Chen Y, Shen X, Fenyk-Melody J, Wu M, Ventre J, Doebber T, Fujii N, Musi N, Hirshman MF, Goodyear LJ and Moller DE: Role of AMP-activated protein kinase in mechanism of metformin action. J Clin Invest 108: 1167-1174, 2001.

6. Evans JM, Donnelly LA, Emslie-Smith AM, Alessi DR and Morris AD: Metformin and reduced risk of cancer in diabetic patients. BMJ 330: 1304-1305, 2005.

7. Bowker SL, Majumdar SR, Veugelers P and Johnson JA: Increased cancer related mortality for patients with type 2 diabetes who use sulfonylureas or insulin. Diabetes Care 29: 254-258, 2006.

8. Ben Sahra I, Laurent K, Loubat A, Giorgetti-Peraldi S, Colosetti P, Auberger P, Tanti JF, Le Marchand-Brustel Y and Bost F: The antidiabetic drug metformin exerts an antitumoral effect in vitro and in vivo through a decrease of cyclin D1 level. Oncogene 27: 3576-3586, 2008.

9. Hawley SA, Gadalla AE, Olsen GS and Hardie DG: The antidiabetic drug metformin activates the AMP-activated protein kinase cascade via an adenine nucleotide-independent mechanism. Diabetes 51: 2420-2425, 2002.

10. Towler MC and Hardie DG: AMP-activated protein kinase in metabolic control and insulin signaling. Circ Res 100: 328-341, 2007.

11. Zou MH, Kirkpatrick SS, Davis BJ, Nelson JS, Wiles WG IV, Schlattner U, Neumann D, Brownlee M, Freeman MB and Goldman MH: Activation of the AMP-activated protein kinase by the anti-diabetic drug metformin in vivo. Role of mitochondrial reactive nitrogen species. J Biol Chem 279: 43940-43951, 2004.

12. Dowling RJ, Goodwin PJ and Stambolic V: Understanding the benefit of metformin use in cancer treatment. BMC Med 6: 33, 2003.

13. Kahn BB, Alquier T, Carling D and Hardie DG: AMP-activated protein kinase: ancient energy gauge provides clues to modern understanding of metabolism. Cell Metab 1: 15-25, 2005.

14. Carling D: The AMP-activated protein kinase cascade - a unifying system for energy control. Trends Biochem Sci 29: 18-24, 2004. 
15. Stein SC, Woods A, Jones NA, Davison MD and Carling D: The regulation of AMP-activated protein kinase by phosphorylation. Biochem J 345: 437-443, 2000.

16. Yun H, Lee M, Kim SS and Joohun HA: Glucose deprivation increases mRNA stability of vascular endothelial growth factor through activation of AMP-activated protein kinase in DU145 prostate carcinoma. Biol Chem 280: 9963-9972, 2005.

17. Neurath KM, Keough MP, Mikkelsen T and Claffey KP: AMP-dependent protein kinase alpha 2 isoform promotes hypoxia-induced VEGF expression in human glioblastoma. Glia 53: 733-743, 2006

18. Lee M, Hwang JT, Lee HJ, Kang I, Kim SS and Ha J: AMP-activated protein kinase activity is critical for hypoxiainducible factor-1 transcriptional activity and its target gene expression under hypoxic conditions in DU145 cells. J Biol Chem 278: 39653-39661, 2003.

19. Ouchi N, Shibata R and Walsh K: AMP-activated protein kinase signaling stimulates VEGF expression and angiogenesis in skeletal muscle. Circ Res 96: 838-846, 2005.

20. Nagata D, Mogi M and Walsh K: AMP-activated protein kinase (AMPK) signalling in endothelial cells is essential for angiogenesis in response to hypoxic stress. J Biol Chem 278 31000-31006, 2003

21. Buzzai M, Jones RG, Amaravadi RK, Lum JJ, DeBerardinis RJ, Zhao F, Viollet B and Thompson CB: Systemic treatment with the antidiabetic drug metformin selectively impairs p53-deficient tumor cell growth. Cancer Res 67: 6745-6752, 2007.

22. Phoenix KN, Vumbaca F and Claffey KP: Therapeutic metformin/AMPK activation promotes the angiogenic phenotype in the ER $\alpha$ negative MDA-MB-435 breast cancer model. Breast Cancer Res Treat 113: 101-111, 2009.

23. Zakikhani M, Dowling R, Fantus IG, Sonenberg N and Pollak M: Metformin is an AMP kinase-dependent growth inhibitor for breast cancer cells. Cancer Res 66: 10269-10273, 2006

24. Tomimoto A, Endo H, Sugiyama M, Fujisawa T, Hosono K, Takahashi H, Nakajima N, Nagashima Y, Wada K, Nakagama H and Nakajima A: Metformin suppresses intestinal polyp growth in $A p c^{\mathrm{Min} /+}$ mice. Cancer Sci 99: 2136-2141, 2008.

25. Luo Q, Hu D, Hu S, Yan M, Sun Z and Chen F: In vitro and in vivo anti-tumor effect of metformin as a novel therapeutic agent in human oral squamous cell carcinoma. BMC Cancer 12. 517,2012

26. Novello C, Pazzaglia L, Cingolani C, Conti A, Quattrini I, Manara MC, Tognon M, Picci P and Benassi MS: miRNA expression profile in human osteosarcoma: Role of miR-1 and miR-133b in proliferation and cell cycle control. Int J Oncol 42: $667-675,2013$.
27. Hidalgo $\mathrm{M}$ and Rowinsky EK: The rapamycin-sensitive signal transduction pathway as a target for cancer therapy. Oncogene 19: 6680-6686, 2000.

28. Collins I and Garrett MD: Targeting the cell division cycle in cancer: CDK and cell cycle checkpoint kinase inhibitors. Curr Opin Pharmacol 5: 366-373, 2005.

29. Merry C, Fu K, Wang J, Merry C, Fu K and Wang J: Targeting the checkpoint kinase Chk1 in cancer therapy. Cell Cycle 9: 279-283, 2010

30. Alimova IN, Liu B, Fan Z, Edgerton SM, Dillon T, Lind SE and Thor AD: Metformin inhibits breast cancer cell growth, colony formation and induces cell cycle arrest in vitro. Cell Cycle 8: 909-915, 2009.

31. Jalving M, Gietema JA, Lefrandt JD, de Jong S, Reyners AK, Gans RO and de Vries EG: Metformin: taking away the candy for cancer? Eur J Cancer 46: 2369-2380, 2010.

32. Montanini L, Lasagna L, Barili V, Jonstrup SP, Murgia A, Pazzaglia L, Conti A, Novello C, Kjems J, Perris R and Benassi MS: MicroRNA cloning and sequencing in osteosarcoma cell lines: differential role of miR-93. Cell Oncol 35: 29-41, 2012.

33. Rocha GZ, Dias MM, Ropelle ER, Osório-Costa F, Rossato FA, Vercesi AE, Saad MJ and Carvalheira JB: Metformin amplifies chemotherapy-induced AMPK activation and antitumoral growth. Clin Cancer Res 17: 3993-4005, 2011.

34. Motoshima H, Goldstein BJ, Igata M and Araki E: AMPK and cell proliferation - AMPK as a therapeutic target for atherosclerosis and cancer. J Physiol 574: 63-71, 2006.

35. Zhuang Y and Miskimins WK: Cell cycle arrest in Metformin treated breast cancer cells involves activation of AMPK, downregulation of cyclin D1, and requires $\mathrm{p} 27^{\mathrm{Kip1}}$ or $\mathrm{p} 21^{\mathrm{Cip} 1}$. J Mol Signal 3: 18, 2008

36. Eastman A: Cell cycle checkpoints and their impact on anticancer therapeutic strategies. J Cell Biochem 91: 223-231, 2004.

37. Tu YS, Kang XL, Zhou JG, Lv XF, Tang YB and Guan YY: Involvement of Chk1-Cdc25A-cyclin A/CDK2 pathway in simvastatin induced S-phase cell cycle arrest and apoptosis in multiple myeloma cells. Eur J Pharmacol 670: 356-364, 2011

38. Zhao H, Watkins JI and Worms H: Disruption of the checkpoint kinase $1 /$ cell division cycle $25 \mathrm{~A}$ pathway abrogates ionizing radiation-induced S and G2 checkpoints. Proc Natl Acad Sci USA 99: 14795-14800, 2002. 